Received: 29.01.2016.

UDK: 005-043.7:37

Preliminary notes

\title{
MANAGEMENT CHANGE IN EDUCATION
}

\author{
Faruk Jašarević \\ Faculty Of Political Sciences University of Sarajevo \\ faruk.jasarevic@fpn.unsa.ba \\ Ermin Kuka \\ University of Sarajevo \\ ermin.kuka@hotmail.com
}

\begin{abstract}
Nowadays, changes have become more universal and essential social and organizational phenomenon. The significance of changes indicated by the fact that they are present at all times of existence of mankind, and it is inevitable that it will be in the future. The changes have become permanent and constantly present facts. It has been proven that today's changes are very broad, rapid, often unpredictable and stressful, but are necessary for each type of development and prosperity. Given the fact that the changes affect almost all aspects of social life and work, this paper will particularly analyze the impact of various changes in the education system. In this context, we will use the method of content analysis of relevant documentary material, as well as the results of previous theoretical and empirical studies of many scientists and researchers in this field. The conclusions that have been reached are a relevant starting point for future action in the framework of educational activities.
\end{abstract}

Keywords: management, change, education, strategy, management, teaching staff

\section{INTRODUCTION}

Changes lead to a comprehensive transformation, as social as well as commercial, political, economic, cultural. When it comes to specific organizational structure and the company, then it is certain that "the traditional companies have to change their business operations and direct them towards new technologies in order to remain competitive in the new conditions. It is evident that the success of the economy of the 21 st century based on 3 I: information, ideas and intelligence "(Cvetković, Kotlica, 2007, p. 85) 
The literature contains numerous classifications and typologies of change, based on different criteria, such as: personal, organizational, global, regional, local, radical, progressive, revolutionary. Change means "process, but the result (of a single) process; changes in the source of the crisis, but also a response to the crisis; change is a challenge, but also a response to the challenge." (Alibabić, 2010, p. 104).

\section{EDUCATION AND MANAGING (MANAGEMENT) CHANGE}

When it comes to the management of scientific views, then it explores and elaborates on change management. Change management is most often associated with the work of organizations and institutions that are changing under the constant influence of the environment, or by the action the so-called innovative organizations and institutions.

Change management is a very complex process and requires quality and softwareoriented enterprises, because in the beginning there is some resistance to change by the majority of those to whom they are directed, and concerned.

The basis of management changes makes strategic management, and the final outcome of change management is determined by quality skills and abilities of all the participant of the process of implementing changes.

Permanent and significant changes are also present in the programs or systems of education and learning. Innovative changes in the educational system are its main propulsion and power development and harmonization of modern social trends.

Practice has shown that in the changing social and working environment only those organizations and institutions that can adapt to these changes can exist and successfully, ie. only those who possess the skills and knowledge of change management. The fact is, when it comes to the education system, particularly to teachers and trainers (educators) of which depends the transfer of new knowledge and skills to younger generations who will take over the burden of social management, development and living (Kuka, 2012).

To implement management changes, it should have its own institutional framework and content. A typical example of such a framework is the "learning organization". It represents a shift from the traditional (conservative) organization to a modern organization that human capital is considered a fundamental factor of his existence and achieve a competitive advantage in the modern world of business and work.

In a changing and turbulent environment, learning is "a fundamental prerequisite for the development of core competence of the organization and their success in response to the new managerial challenges" (Alibabić, 2010, p. 112).

Numerous definitions of the phenomenon of a learning mostly on the fact that learning organization is the essence of action and existence of such organization.

It supports continuing education (in particular through various forms of formal and informal education and learning of their employees), and enables their employees to develop critical thinking and reasoning with the purpose of better understanding of what they make and do. The learning organization is one type of business and educational organizations, as it is done within the knowledge transfer to employees, and the same 
knowledge that employees use in creating and producing the final product (tangible or intangible). Therefore, a learning organization is an organization that "owns systems, mechanisms and processes, and organizational infrastructure for the promotion and development of its members, and in order to achieve organizational goals and objectives of the community in which the organization works" (Kulić and Despotović, 2005, p. 118).

We can rightly say that a learning organization, as an example of management changes, based on knowledge and education, is a kind of institutional framework within which to study and explore the changes and learning how and how to manage the changes necessary for a future organizational survival and construction and retaining competitive advantage.

Management changes within itself combines managerial and leadership competencies, and they include: rationality, economy, perseverance, reflection, authority, creativity, flexibility, mobility, innovation and great attention to initiating change and power. Therefore, the very managers should continuously learn and educate themselves, thus linking capacity for learning and positive attitudes and thinking about learning and education. According to Šefika Alibabić, there is no change in education unless there is no "positive understanding and perception of education, to embrace change as a challenge for further (lifelong) learning, acceptance and teamwork skills in teaching and learning, and understand themselves as lifelong learners. The essence of management changes in the organization makes management adult education and learning, which includes the right of the competence necessary for the success of one of the role of adult educators the role of manager of education and learning, and managers of change." (Alibabić, 2010, p. 117).

\section{EDUCATION AS A COMPETITIVE ADVANTAGE}

Competitiveness, as a phenomenon of the modern age, social and business activity, implies a stable and strong position of a certain entity (organization or institution) in relation to other entities whose activities are equal or identical. In order for an organization or institution to be competitive, it needs to have adequate and strong resources that will allow strong and effective action (business).

The competitiveness of every organization arises from the characteristics and resources that they possess and to allow for adequate and effective positioning in the market, so that it can be superior and more powerful compared to direct competitors belonging to the particular sector or activity or areas of activity.

In order to achieve a competitive advantage, it is necessary that the organization meets the following three factors (Zubović, 2010, p. 57):

1. 1. Must be different from the competition,

2. 2. This diversity should generate economic usefulness and

3. 3. Critical factor in organizational success must be such that the competition can not easily imitate.

Nowadays, the human factor of economic progress and prosperity is increasingly 
gaining in importance, and often has a critical role in organizational success. Knowledge and innovation that is the product of knowledge, become the basic factors of survival and further development in every aspect. Therefore, special attention is devoted to human resources, the knowledge and skills they possess, and which acquire during their formal and informal education and training. Particularly important form of education and human resources development is non-formal education, whose practice is voluntary and is not under a strict obligation, and which gives importance of increasing the attractiveness and influence.

At the end of the 20th and early 21st century there has been a large increase in interest in knowledge (education), which is now considered the only guarantee to achieve competitive advantage of the organization (whether it is a for profit or nonprofit organizations). The survival of the organization depends on its ability to adapt to the dynamics of an adequate environment in which it operates. This requires that the organization possess, investigates and analyzes various information from their environment, but the job requires an approach that can be implemented only under the condition that the organization has competent and educated people. Such personnel are able to analyze and process information from the environment and to harmonize their activities in line with what the market demands and requests. Creating and transferring knowledge within the organization becomes "a decisive factor in achieving and maintaining its competitive advantage” (Đorđević-Boljanović, 2009, p. 21).

So, it is not enough just to achieve the current competitive advantage, but it is necessary that advantage and position held in the future. This task is implemented permanent and continuous education of the employees and managers of the organization, all these activities should be carried out through a system of formal and informal education and training. Therefore, a fundamental element of sustainable competitive advantage of modern organizations is precisely the knowledge that the organization or its managers and employees have, how effectively use this knowledge, and how quickly an organization acquire and use new knowledge. Modern organizations is just one organization that learns, remembers and acts in the era of knowledge based on the available information and knowledge.

Education, as the competitive advantage of modern organizations is significant because of the fact that employees within these organizations acquire adequate knowledge of consumers (clients) and the reasons for their cooperation with the organization. But such a transfer of knowledge should be based on already mentioned "learning organization".

Transforming organizations from industrial society to a knowledge society, which occurred 80's and 90's of the 20th century, was not possible without the action of a wide range of management concepts. These concepts are: "The learning organization, intellectual capital, core competence, TQM (Total Quality Management), Business Process Reengineering, Knowledge Management and others' (Đorđević-Boljanović, 2009, p. 21).

Therefore, it can be reasonably concluded that any organization is successful and competitive as much as the educated and successful its employees. For education and 
staff development are capital investment and quality that lasts. Modern innovative organizations have fully recognized the crucial role of education in achieving competitive advantage and have adopted the concept of human (intellectual) capital as the most important development resource. Knowledge is, for such an organization, a resource for improving production and productivity. Therefore, the organization will be fully occupied with training and development of its employees and managers in the future and seek, through fertilization its own intellectual capital, achieve and maintain a competitive position and advantage in an uncertain market competition.

\section{EDUCATIONAL NEEDS AND STRATEGIES}

The strategy is in all segments of activity, even in the educational area, one of the most interesting phenomena of our time. Quite obvious is the fact that without active and developed strategy of action there is no quality work nor the quality of the final success.

At the present time, the strategy is met under different names, such as: organizational strategy, business strategy, corporate strategy, strategic management and others. Etymologically, the word strategy derives from the Greek word "strategus", which translated into our language means "an individual with a high military rank in Ancient Greece" (military officers with broad powers). Over time, due to rapid and comprehensive changes, there was a need to introduce strategies (strategic management) in the educational process. In this regard, the majority of scientists and researchers agree that the process of strategic management involves four main components (Miljkovic, 2009, p. 26):

1. Analysis of environment,

2. Formulation of strategies,

3. Implementation of strategies and

4. The control of strategy implementation.

In this case, particular attention was paid to the educational needs, ie. analysis of the environment as a starting component and the starting point of strategic management. Analysis of the environment, according to Fikreta Bahtijarević-Šiber, means "the basis for management decisions about what actions to take now and in the future in order to improve the competitive position of the organization." (Bahtijarević-Šiber, 1999, p. 143).

Through analysis of the environment leads to knowledge and knowledge of the needs and desires of interest groups (stakeholders) belonging to a particular organization or institution. Therefore, the environmental analysis is required in the process of education, because this analysis provides an adequate, true and verifiable information on the educational needs of that rule within a specific community (society in general). From identifying and adapting activities to those needs depends on the quality of the educational process and the entire education system. This fact is especially important for non-formal education, which is a lot more flexible and quickly adapts to changes and needs in relation to formal education. In this connection, the foundation of today's significance and role of informal education in the world lies in the fact that the informal 
system of education most effectively recognizes the educational needs of the population and provides programs and content of education adapted to these needs. Active signals and information that come from the environment are the main indicators of the current represented the dominant social needs to be an adequate and effective way to meet.

In the external environment, organization or institution that provides formal and informal education, 1 is an interactive relationship with the participants who are in that environment. In the first place are the consumers, or users of educational services. Therefore, the education strategy can be characterized as planning to implement the set concept (mission and vision), a product (the result) of its impact on the educational needs is good quality and flexible educational system aimed at satisfying the current demands, interests and needs of the users of educational services.

Educational strategies are based on the concept of life-long learning encompasses all educational paths (Damjanović, 2006, p. 58-59):

- Formal school education is carried out in the school and is open to all ages;

- Informal Extracurricular education is the education of a more flexible organization that can be realized in the context of different teaching methods, and is intended for adults and children;

- Self-education is a form of education that self-organized person who learns with and without instructions, and occurs as a function of supplement school learning, but also out of it and take it and young adults;

- Informal education is spontaneous and unplanned learning through a variety of life situations.

All these educational pathways mostly talk about how much are awareness and practice developed to adequately meet the educational needs of humanity. The strategy not only recognizes the educational needs of ordinary workers (employees), but also a wide range of educational needs of executives and officers (managers), which covers the entire social system of education needs.

The basis of designing the strategy of program structure functional training and development of executives are as follows (Brekić, 1994, p. 193):

1. The system of training and knowledge innovation is set to be in line with the role and influence of the executives on the efficiency and the development of modern enterprise organization in the changed economic conditions;

2. The program should provide the knowledge to the manager and information necessary to perform this profession in a modern way, and enable them to constantly innovate existing knowledge;

3. Programme structure is flexible, which will be updated on the basis of research results typology of managerial functions and skills necessary to perform them in practice.

It is evident that without an adequate strategy in the work of educational organizations and institutions it is not possible to identify needs accurately and with great quality, on the one hand, and set up programs and facilities of education that will enable the satisfaction of these needs in accordance with the current requirements and standards of the labor market, on the other hand. If the strategy is bad, it is bad and evaluation of educational needs, and that the educational system, and therefore the whole 
society, will tolerate such a situation and not be able to efficiently and successfully operate and develop in the future. Meeting the educational needs is one of the cornerstones of progress and prosperity of any society.

\section{MANAGEMENT IN THE FUNCTION OF TRAINING THE TEACHING STAFF}

The place of management in the education system is very important and indispensable to raise the qualification of teachers-lecturers. In order for education system to adequately operate and meet the challenges that arise in the context of skilled activities, the system must be able to recognize and accept positive educational achievements that are every day more and more present and more advanced. Therefore it is necessary that organizations and institutions dealing with educational activities, have, in addition to financial and infrastructure resources, well developed human resources ie. trained, professional and competent teachers-lecturers capable of new knowledge and skills required by modern labor market, quality and efficient transfer to the participants of educational programs. Slow and poor quality teaching staff with anachronistic and conservative curricula, can not give a positive and high quality results. Therefore, in addition to the continuing education of broad social masses and senior civil servants, for the success and further development, it is very significant and continuing professional education of those who directly carry out educational programs, such as teacher-trainers.

Precisely, the main reason why the management at the present time is so important is that you as the "management" deal with people. Its task is to equip people for a team (joint) operation. In addition, management encourages and supports its own power, and eliminates their weaknesses "(Jašarević, Kuka, 2016, p. 87). As part of the educational activities these items are crucial, because qualified teaching staff means a fully qualified educational organization and institution.

In regards to this, the role of management is very large and very important. Management is the one who provides "natural conditions and the motivation of employees to acquire and maintain adequate intellectual-professional shape” (Žiga, 2003, p. 48). Managers of educational organizations and institutions should motivate their teachers, and they affirm and support in their personal professional development and education.

Also, managers are the ones who need to identify best practices for the acquisition or transfer of new knowledge and information necessary for teaching staff. For, "in education, we must find a way to the entrepreneurial environment offer a specific service that monitors the tendency and trend of informatization" (Delač, and associates, 2016, p. 55). This will enable educational organizations complete offer to management of these specific educational services as a key tool for participation in risky entrepreneurial and competitive environment. Professional training and education of teaching staff can be thought of as "the sum of all formal and informal learning experiences and during the career of a teacher, from graduation to retirement, or all formal and informal experiences that help the teacher to develop a new quality of understanding of pedagogy and their 
own practice to constantly expanding their knowledge base "(National report on the development and state of adult learning and education, 2008, p. 13).

In most cases, planning of professional training and education of teachers is implemented in the framework of the preparation of the annual plan of educational organizations or institutions. In regards to this, there have been developed various forms of professional training and education of teachers, starting with various seminars, conferences, workshops... The objectives of such education programs are:

1. Introduction of teaching staff to new developments (innovations) in the field of scientific research;

2. training of teachers in the application of new methods and techniques;

3. adequate preparation of teachers to successfully respond to new educational needs posed by the labor market;

4. introduction and training of teachers in how to innovate in the system of their work;

5. training of teachers to evaluate critical thinking of those transfers of knowledge, and how to motivate them to do so, and others.

All these program activities can not be organized and implemented in the right way without the involvement of management in the process, ie. without the active role of managers (directors, deans, rectors) educational organizations and institutions. A good manager thinks of his staff and their continuing education. Such an approach is a prerequisite for producing quality personnel trained to respond to modern demands posed by the labor market. If an organization or institution producing such a frame, then it achieves general reputation and competitive advantage and attractiveness in relation to the other.

High quality and professional staff is the key to organizational success, and the staff at educational organizations and institutions are, in addition to managers, administration staff. In regards to this, many managers of educational organizations and institutions are introducing a system of evaluation of their teaching staff, by conducting survey and other studies, where participants or beneficiaries of educational services, evaluate the work of their teachers (lecturers). Results of this research are very important for managers in making future with proper decisions, as well as being one of the main ways of identifying competence of the teaching staff, and the causes of their eventual release.

Since the late 80's of the 20th century, the European Union (EU) has given a special importance to the situation of teachers, their education and training. At the conference in Helsinki (Finland) in 1987, they've singled out the main problems faced by teachers at the beginning of the 90s, as it is today, in European countries, it is as follows (Cvjetićanin and Segedinac, 2008, 110):

- The growing heterogeneity of the school population (characterized by different range of skills, interests and social origin);

- A huge increase in the quantity of information and their impact on the content of the curriculum;

- Competition between alternative sources of information, especially the mass media with contradictory values and influences;

- The introduction of new teaching methods, particularly those based on the use of 
new information technologies;

- Opening the school to the outside world and different expectations of this world compared to the teachers and their work.

\section{CONCLUSION}

Changes have become the essential features and characteristics of contemporary living and work in almost all areas. Being prepared for such changes, and be prepared for them adequately, effectively and timely respond has become the essence of every action. In regards to this, the preparation for the coming change, is key to the success of any organization, company, institution. This is a prerequisite for securing a competitive advantage in the functioning and operation, which greatly affects the existence and survival of the organization in an increasingly changing and risky environment. This is especially true for educational organizations and institutions, which will inevitably have to follow the ongoing changes in educational activities, in order to offer high quality and market-oriented educational programs. Because more and more attention is paid to the conformity of educational programs to market demands with the primary objective of reducing the rate of the general level of unemployment. Unemployment is a problem faced by many countries in the world. Incorporation of management in this process is certainly one of the key and important tools and mechanisms of ensuring marketoriented educational programs. The incorporation of strategic management, which monitors changes in the environment, is the initial phase of movement towards this end.

In regards to this, the further development of the educational sector requires a growing influence of management and managers. In this context, it is particularly important impact management and managers to raise the level of qualification of the teaching staff, of which depend upon the transfer of knowledge and skills of the future workforce and overall success and prosperity of society. Managers have a special role in this process, because they provide a link between past and future, as well as the external environment and internal capabilities and capacities, ie. they supply manpower to labor market. To intensify the introduction of management, both within the market, as well as in the framework of education is a precondition for achieving a balance and compromise the supply and demand for high-quality, educated, trained and qualified staff in the labor market. Only such staff is ready to participate in a strong and competitive market competition.

\section{REFERENCES}

1. Alibabić, Š. (2010). Obrazovanje i učenje odraslih-jezgro menadžmenta promene. Obrazovanje odraslih, 10(1): 103-118.

2. Bahtijarević-Šiber, F. (1999). Menadžment ljudskih potencijala. Zagreb: Golden marketing. 
3. Brekić, J. (1994). Inovativni menadžment. Zagreb: NP Alinea.

4. Cvetković, N. Kotlica, S. (2007). Nova ekonomija u svetu koji se menja. Beograd: Megatrend univerzitet.

5. Cvjetićanin, S., Segedinac, M. (2008). Mogući pravci permanentnog obrazovanja učitelja u primeni eksperimenta. Obrazovanje odraslih, 8(2): 109-122.

6. Damjanović, P. (2006). Strateško planiranje u obrazovanju. Banja Luka: Zavod za udžbenike i nastavna sredstva Istočno Sarajevo.

7. Delač, D., Graovac, P., Pavlinović, M. (2016). Specifičnost učenja za poduzetništvo u online okruženju. Obrazovanje za poduzetništvo, 6(1): 45-57.

8. Đorđević-Boljanović, J. (2009). Menadžment znanja. Beograd: Datastatus.

9. Jašarević, F., Kuka, E. (2016). Menadžment cjeloživotnog učenja i neformalnog obrazovanja u službi razvoja Bosne i Hercegovine. Obrazovanje za poduzetništvo, 6(1): 85-98.

10. Kuka, E. (2012). Menadžment u obrazovanju. Sarajevo. Štamparija Fojnica d.o.o.

11. Kulić, R. Despotović, M. (2005). Uvod u andragogiju. Zenica: Dom štampe.

12. Miljković, J. (2009). Model upravljanja institucijom za obrazovanje odraslih. Obrazovanje odraslih, 9(2): 21-32.

13. Nacionalni izvještaj o razvoju i stanju učenja i obrazovanja odraslih (ALE) - Nacionalni izvještaj Bosne i Hercegovine (2008). Sarajevo: IIZ/DVV Ured Sarajevo.

14. Termiz, Dž. (2009). Metodologija društvenih nauka (drugo dopunjeno i prošireno izdanje). Lukavac: NIK Grafit.

15. Zubović, J. (2010). Razvoj privrede zasnovan na ulaganjima u ljudske resurse i stranim investicijama. Beograd: Institut ekonomskih nauka.

16. Žiga, J. (2003). Uloga menadžmenta u obrazovnim ustanovama na podizanju stručne osposobljenosti nastavnika. Obrazovanje odraslih, 3(1): 45-53. 